Kuhn L. W., 1970: Mole control. [In: Proceedings 4th Vertebrate Pest Conference. Dana R. H. ed.], 71-76. West Sacramento, Calif. - McMullan E. E., 1972: Methods of analysis. Part 2. Soils. Biochem. Lab. Serv. Can. Forest. Serv. Bull. No. BC-X-67. Victoria, B. C. - Satchell J. E., 1955: Some aspects of earthworm ecology. [In: Soil Zoology. Kevan D. K. McE. Ed.]. Butterworths. 180-201. London. - Schaefer V. H., 1979: Aspects of habitat selection in the coast mole (Scapanus orarius True) in British Columbia. Simon Fraser University Ph. D. Thesis. 205 pp. Schaefer V H. \& Sadleir R. M. Factors influencing molehill densities in pastures. Mammalia (in press). - Shilova S. A., Denisova A. V., Dmitriev C. A., Voronova L. D. \& Bardier M. N., 1971: Effect of some insecticides upon the common mole. Zool. Ž., 50: 886-892 [In Russian]. Wick W. A., 1961: Mole control takes some doing. Oreg. Farm. 84: 5-6.

Accepted, September 25, 1980.

\title{
Verification of Censusing Techniques for the Wyoming Ground Squirrel
}

\author{
OCENA METOD WYEOWU SPERMOPHILUS ELEGANS
}

\section{David A. ZEGERS1}

Zegers D. A., 1981: Verification of censusing techniques for the Wyoming ground squirrel. Acta theriol., 26, 7: 123-125 [With 1 Fig.]

Direct counts and the minimum number known to be alive derived from capture-mark-release data gave essentially the same density estimates for a montane population of Wyoming ground squirrels, Spermophilus elegans.

[Dept. Environment., Population and Organismic Biol., Univ. Colorado, Boulder, CO. 80309, USA]

Verification of the accuracy of censusing techniques is an important but ofter neglected research activity. Basically, accuracy can be assumed 1) when utilizing a technique on a population of known size gives results similar to that known density or 2) when two completely independent census methods produce comparable results (Bergerud, 1968). The objective of this study was to test the precision of censusing techniques for Wyoming ground squirrels, Spermophilus elegans elegans Kennicott, 1863.

During the summer of 1975 , the animals were studied in a montane meadow ( $2440 \mathrm{~m}$ elevation above sea level) on the eastern slope of the Front Range of the Rocky Mountains, approximately $16 \mathrm{~km}$ southwest of Boulder, Colorado, USA (Zegers \& Williams, 1979). The study site of 3.6 ha was located in the center of a gently sloping, bowl-shaped 76-ha horse pasture.

Two censusing techniques were used and compared. The first was a CMR procedure that involved catching the squirrels with National live-traps (\#201) and marking them with ear tags and freeze-brands such that individuals would be recognizable at a distance (Hadow, 1972;

${ }_{1}$ Present address: Dept. Biol., Millersville State Coll., Millersville, Pa. 17551, USA. 
Zegers, 1977). The area was retrapped at intervals throughout the summer (see Fig. 1). For each two-week period from 20 April to 10 August the minimum number known to be alive, as estimated by the Jolly (1963) model, was calculated using a computer program prepared by Krebs (1972).

The second censusing procedure involved direct counts of all individuals visible within the 3.6 ha study area. These data were collected on seven days in 1975 from approximately 0900 to 1000 hours on warm sunny mornings which were typical of times of peak ground squirrel activity (Zegers, 1977). Because these squirrels were colonial, sedentary, and highly visible in their open and rather flat habitat, I was able to use a $20 \times$ spotting scope and rapidly count all the individuals in the study area.

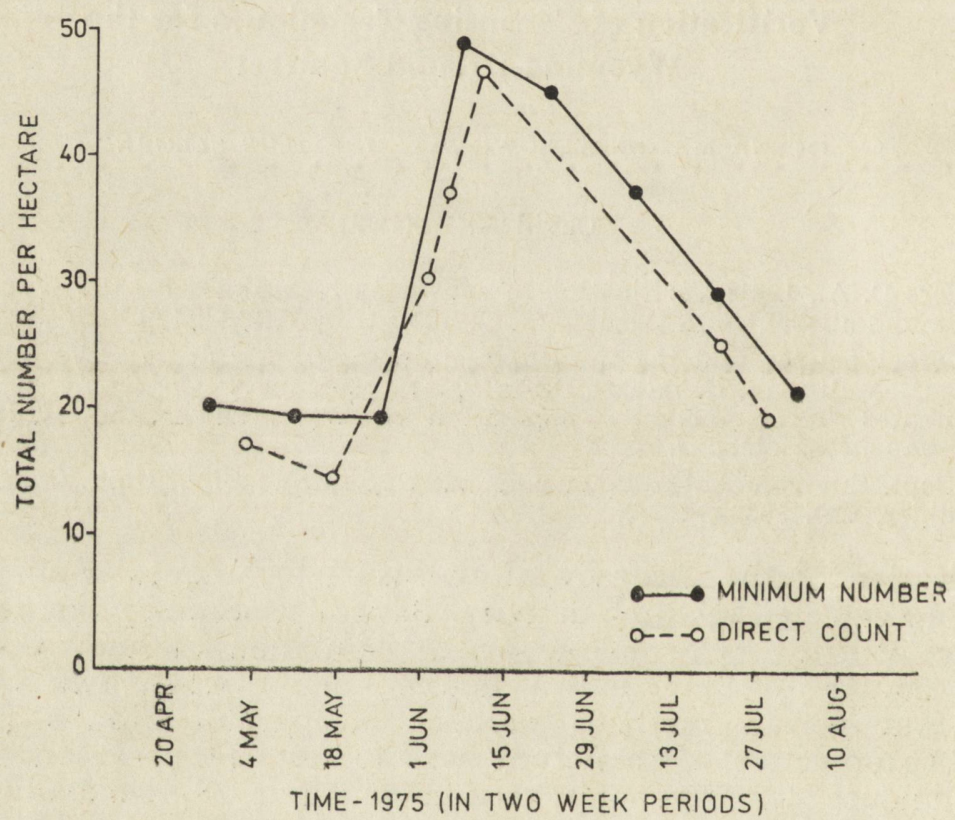

Fig. 1. Comparison of density estimated by direct count and the minimum number known to be alive for Spermophilus elegans elegans.

The results (Fig. 1) show density estimates for these two techniques to be essentially the same. Correlation between the two is high with $r=0.99(p<0.001)$. That the direct count was always slightly lower than the minimum number estimate is because even under optimal environmental conditions a few individuals were either out of the study area or else under ground and therefore not visible.

These estimates may be equally valid or equally biased. However, because the techniques are independent of one another and because they produce similar estimates of density, their accuracy is probably good.

Several factors contributed to this result. First, direct counts were facilitated because of the characteristics of $S$. elegans described above. 
Secondly, because they are easily captured and because they have rather small home ranges, a high percentage of the population can be marked thus reducing the chance of error in calculation of the minimum number known to be alive. Therefore, although $S$. elegans provides an ideal opportunity to test these censusing procedures, application of the results to other species is limited. Nevertheless verification of censusing techniques is an important aspect of ecological research that should not be neglected.

Acknowledgements: Sigma $\mathrm{Xi}$ and the Kathy Lichty Memorial Fund of the University of Colorado provided financial aid. Dr. Olwen Williams gave many useful suggestions and guidance. Dr. Steven Telleen assisted with some of the field works. Dr. Guy Steuek performed the statistical analysis. James Ha and Drs. D. McCracken and G. Steuei made helpful suggestions when reviewing the manuscript.

\section{REFERENCES}

Bergerud A. T., 1968: Numbers and densities. Pp 21-42, [In: »A practical guide to the study of the productivity of large herbivores", F. B. Golley and H. K. Buechner, eds.]. IBP Hdb. No. 7, Blackwell Sci. Publ.: 1-308, Oxford. Hadow H. H., 1972: Freeze-branding: a permanent marking technique for pigmented mammals. J. Wildl: Manage., 36: 645-649. - Jolly G. M., 1963: Estimates of population parameters from multiple recapture data with both death and dilution - deterministic model. Biometrika, 50: 113-128. - Krebs C. J., 1972: Computer programs for analysis of demographic data from small mammal populations. 17 pp. mimeo. - Zegers D. A. 1977: Energy dynamics and role of Richardson's ground squirrel (Sphermophilus richardsonii elegans) in a montane meadow ecosystem. Ph. D. thesis, Univ. Colorado, Boulder 177 pp. - Zegers D. A. \& Williams, O., 1979: Energy flow through a population of Richardson's ground squirrels. Acta theriol., 24: 221-235.

Acrepted, October 3, 1980.

\section{Secondary Sex Ratio in Siberian Tigers, Przewalski Horses and European Bisons}

STOSUNEK PŁCI U TYGRYSA SYBERYJSKIEGO, KONIA PRZEWALSKIEGO I ŻUBRA

\section{Luděk BARTOŠ}

Bartoš L., 1981: Secondary sex ratio in Siberian tigers, Przewalski horses and European bison's. Acta theriol., 26, 7: 125-128.

[Res. Inst. Anim. Prod., 25161 Praha 10 - Uhřiněves, Czechoslovakia].

There are many publications on the sex ratio of various mammalian species, mainly laboratory animals. The aim of this paper was to analyse three species kept in zoos, for various factors in connection with the sex ratio of their progeny. These were the Siberian tiger Panthera tigris altaica (Temminck, 1844), the Przewalski horse Equus przewalskii, Poliakov, 1881, and the European bison Bison bonasus (Linnaeus, 1758). All the data used were obtained from the pedigree books of individual species, and cover progeny registered in zoological gardens all over the world, during the period $1940-1976$ in Siberian tigers (Seifert \& 